\title{
Re-Regulating Offshore Finance?
}

\author{
B. Maurer*
}

Department of Anthropology, University of California, Irvine

\section{Abstract}

This article explores global efforts to regulate offshore finance in the wake of international concern about the effects of so-called harmful tax competition, as well as money laundering and terrorist financing (the latter a relatively new category since September 11, 2001). In the mid-1990s, a number of multilateral organizations, from the Organization for Economic Cooperation and Development (OECD) to the Financial Action Task Force, as well as non-governmental organizations like Oxfam, attempted to curtail offshore finance and tax haven abuses by "naming and shaming' small jurisdictions into compliance with an emerging set of international financial norms. These efforts left themselves open to charges of hypocrisy, however, because many OECD countries themselves failed - and indeed, still fail - to adhere to the standards required of offshore havens. Tax havens responded by calling for a 'level playing field'. Nevertheless, this effort at global regulation of offshore finance has had tangible effects. This essay explores those effects and argues that the attention to offshore finance missed an opportunity by going after the jurisdictions that provided services rather than addressing the market for such services. Understanding that missed opportunity requires analytical attention to payments, as opposed to exchanges, in international finance and in the social study of finance.

'Only the little people pay taxes.' - attributed to Leona Helmsley, 1989

The 10 years between 1996 and 2006 witnessed intensified global efforts to regulate offshore finance. The United Nations, the Organization for Economic Cooperation and Development (OECD), the Financial Action Task Force (FATF), the Financial Stability Forum (FSF), the International Monetary Fund (IMF), the European Union, and non-governmental organizations including Oxfam, Christian Aid, and the then-newly formed Tax Justice Network (TJN) all issued reports and declarations urging an end to abuses of fiscal and financial systems they saw as caused by offshore financial activities in so-called tax havens. On the other side, the Society for Trust and Estate Practitioners, the leaders of Caribbean countries, the Commonwealth Secretariat, and lobbying groups like the US-based Heritage Foundation, the Cato Institute and newly formed entities like the Center for Freedom and Prosperity and the International Trade and Investment Organization all aligned to challenge these efforts at global 
regulation. Given the intensified attention to offshore finance, in 2002 Hampton and Christensen thought the days of offshore finance were numbered and speculated about the post-offshore future for many small island economies that had become dependent on financial services, like the British Virgin Islands and Jersey. While many observers would say that the effort to rein in offshore finance has tapered off if not altogether failed, these are still important concerns, especially for small and vulnerable island economies with few other prospects in the global economy (Sanders 2005; Vlcek 2007). Regardless of their success or failure, these multiple, overlapping, and sometimes contradictory initiatives have resulted in renewed scholarly and policy attention to offshore finance, and this renewed attention compels a reassessment of what offshore is, how it can be apprehended, and how it is important to understanding contemporary shifts in global economic and social geographies.

Furthermore, the initiatives against offshore hold lessons for social science more broadly, at a time when the social study of finance is coming into its own as a subfield of anthropology, geography, sociology, and allied fields (for reviews, see de Goede 2005 and Maurer 2004). Elsewhere I argue that one of those lessons has to do with the changing nature of law, because the initiatives against offshore finance relied not on standard international legal or regulatory practices but rather 'soft law': naming-and-shaming, peer review, and peer pressure (Maurer 2008). Although, as we shall see, the effort to re-regulate offshore finance did lead to the creation of new 'hard' law instruments like enforceable treaties, the initiative itself was based on non-binding, normative deliberations that stand outside of formal international law. Such 'soft law' innovations in international policymaking are interesting for scholars studying the privatization of governance and the emergence of new global regulators that are not beholden to standard democratic processes. They also, of course, pose moral and political dilemmas for those who believe in the normative and ethical superiority of democratic process over private arbitration or negotiation.

My main argument in this essay, however, is that the effort to re-regulate offshore finance requires a return to the old insight from economic anthropology that there is a difference between exchange and payment. Like soft law, the distinction between exchange and payment brings to the fore the moral implications of offshore finance and policy responses to it. Exchange and payment are often conflated, and the fact that the English language uses payment to mean both the giving of a sum of money in exchange for goods or services and the discharging of an obligation or debt does not help matters. Indeed, offshore finance centers and tax planners can make use of this conflation, because exchanges can be disguised as debts and debts cannot be taxed. The more ancient meaning, the discharging of an obligation, is from the same root as the verb 'to appease', and does not imply the sense of reciprocity entailed in exchange, a more modern term (Oxford English Dictionary). By exchange, I point to the marking of goods 
and services to market on one scale of value; and by payment, I index relationships of rank and notions of value not directly linked to markets and their mathematics of equivalence (see Guyer 2004). There are numerous lessons for the social study of finance in the initiatives to regulate offshore finance, and while these shall occupy the bulk of my story here, the reader is encouraged to keep in mind the distinction between payment and exchange, for I will return to it at the end of this essay. For now, suffice it to say that the distinction bears on one of the practical solutions to the problem of offshore finance. This solution is to pay jurisdictions not to allow offshore finance in their territories; that is, to buy them off (Sharman 2005). Payment can help solve the intractable moral dilemma of attacking offshore finance without writing off small island economies as necessary casualties of a new global economy. This solution, however, comes up against the same dilemma that leads wealth offshore in the first place: the normative commitment to exchange over payment, and the elevation of the free market of atomized exchange over relationships of obligation, fealty, and appeasement. The former feels like liberty; the latter, like despotism. This may need to change if we are to imagine alternative, and more just, economic geographies and political economies. ${ }^{1}$

The essay is divided into five sections. First, it reviews various definitions of offshore finance, its scale and scope, and the operations that can take place offshore. Second, it chronicles the emergence of the idea of 'harmful tax competition', which became central to the policy debate and the normative deliberations around offshore that took place in the 1990s. Third, it turns toward offshore financial service centers' responses to these deliberations and the construction and deployment of an alternative norm, that of the 'level playing field', an idea that placed fairness - that is, equal treatment for all countries and jurisdictions - above any possible harm caused by the competitive lowering of tax rates globally. The fourth section examines some of the effects of the initiative against tax competition. Finally, the fifth and concluding section returns to the question of payment, and the moral anxiety around payments in a world infused with market ideologies that emphasize exchange. For it is the norm against payment that both leads people offshore in the first place, and that lies in the way of a practical policy response to the problem of offshore finance itself.

\section{Offshore Finance: An Overview}

What is offshore finance? There is a significant literature on the dimensions and definitions of the offshore. The first definitional quandary is whether offshore refers to a place or series of places on the one hand, or a phenomenon of financial flows on the other hand. The conflation of offshore finance with so-called tax havens has tended to focus the research on specific jurisdictions linked in a wider process, rather than placing primacy on the processual aspects of the offshore. This leads to definitions like Hampton's 
(1994): places that 'host financial activities that are separated from major regulating units (states) by geography and/or by legislation' (p. 237; see Hampton and Abbott 1999). Roberts similarly focuses on the separation of the offshore from nation-states' economies, but places emphasis on the markets rather than the jurisdictions that these markets employ (Roberts 1994, 93). Palan, noting the 'wide range of definitions', settles on one that weighs place and process equally, for 'the transactions that constitute the offshore economy' take place in 'specially designed jurisdictional enclaves distinguished from their onshore counterparts by the removal of some or all state regulation' (Palan 2003, 19). The IMF uses the following definition:

- Jurisdictions that have relatively large numbers of financial institutions engaged primarily in business with non-residents;

- Financial systems with external assets and liabilities out of proportion to domestic financial intermediation designed to finance domestic economies; and

- More popularly, centers that provide some or all of the following services: low or zero taxation; moderate or light financial regulation; banking secrecy and anonymity (IMF 2000, www.imf.org/external/np/mae/oshore/2000/ eng/back.htm).

The IMF has also compiled lists of offshore financial centers based on various criteria (www. internationalmonetaryfund.com/external/np/mae/oshore/ 2000/eng/back.htm\#table1).

As Hampton, Roberts, and Palan have ably documented, the relationship between state sovereignty and markets that escape or circumvent the state has long been the animating problematic of research on offshore finance. Some scholars emphasize the legal construction of the offshore, in particular the disaggregation or unbundling of citizenship, jurisdiction, and nationality (Maurer 1997; Picciotto 1999). Others focus more on the political philosophy of sovereignty and the centrality of the offshore to the sovereign state system (Palan 2003). Indeed, the aftermath of the initiatives against offshore finance reviewed in this essay exemplifies the paradox that offshore, seemingly working at cross-purposes to sovereign states, can in fact bolster state sovereignty. In this case, efforts to regulate offshore finance ended up enhancing small states' sovereign power to forge treaties with their more powerful neighbors (Rawlings 2007).

Debates over the nature of offshore finance tend to focus on the following series of questions: whether offshore is a consequence of the system of state sovereignty or a consequence or a cause of global financial liberalization; whether offshore is an effect of the law or an effect of markets and inherent structural tendencies in capitalism; whether offshore is part of a longue durée story about conflicts among elites in offshore jurisdictions, linked to local development efforts, or delinked from national(ist) aspirations in those jurisdictions; or whether offshore is an index of a new postmodern political geography (see, variously, Donaghy 2002; Donaghy and Clarke 2003; 
Hampton and Abbott 1999; Hudson 1998, 2000; Maurer 1997; Palan 2003; Picciotto 1999; Rawlings 2004, 2005; Roberts 1994; Sharman 2005, 2006). Because the purpose of this essay is not to review this literature, but rather to understand the countermeasures attempted against offshore finance in the period between 1996 and 2006, I will not linger over the rich debates and distinctions among scholars who have taken up these questions. Others have done the work of analyzing the historical development of the offshore financial services sector (Picciotto 2007 and Palan 2003 offer comprehensive discussions).

What you can do offshore? First, it is a truism that any jurisdiction with lower tax rates or more favorable secrecy laws can serve as a tax haven for someone from a more closely regulated place. Many jurisdictions specifically (and often pejoratively) labeled a tax haven offer different rules for nonresidents, as well as a high degree of bank deposit and/or corporate ownership secrecy. Proponents would say that such jurisdictions offer opportunities for tax, estate, and corporate planning, rather than tax evasion or money laundering. Offshore finance is essential to the business of multinational corporations, trade financing, and insurance, as well as to pensions and more exotic financial instruments like derivatives and hedge funds. At the most basic level, they provide for the mitigation of risk and around-the-clock movement of assets, as well as the efficient handling of foreign exchange between banks and corporations. They allow for corporate and real persons to deal with income streams from different jurisdictions without having to face double-taxation issues. Because the payment of taxes in different jurisdictions can become a large component of a corporation's or wealthy person's balance sheet, the movement of assets offshore or into different trust entities can be an important form of 'asset protection' and an important part of any risk reduction strategy: it is good, from a fiduciary perspective, to have assets spread into multiple vehicles and multiple locales (Rawlings 2005).

Furthermore, offshore finance can be used to disguise the nature of profit and thereby also confuse the distinction from wealth earned through exchange and payments based on obligation. Braithwaite $(2001,32)$ provides the following example, loosely based on an actual case, which I quote at length because it so richly captures the dynamics among profit, payment and debt, as well as charity and obligation:

The HWI [High Wealth Individual] has a million dollars in profit. He gets a charitable deduction by donating it to a breast cancer research foundation he sets up in Geneva. The foundation then almost immediately lends it back to the HWI at an exorbitantly high interest rate. This interest rate enables the company that pays it to record a loss that the HWI can then write off against profits in another company he controls. The HWI gets a million dollars back and two tax write-downs: a deduction on the way over to Geneva and a loss he can use to reduce taxes on the way back from Geneva. If he disguises the transactions effectively, it almost certainly won't be detected. If it is, the HWI 
has reputable people organized to testify that he always fully intended to repay the loan. He can actually do so before the matter goes to trial. The Director of the Breast Cancer Research Foundation will testify that they wanted to use the money well, to wait until a research proposal came along that would really produce a medical breakthrough. But while they were waiting they wanted to put their money to work. They knew that their benefactor, the HWI, knew how to do that better than they. And he was generous enough to pay an above-market interest rate to ensure that all the profits from his investment would be passed back to the Foundation. The Tax Office decides it does not want a case where a judge might vilify it for persecuting a businessman dedicated to such a cause. ${ }^{2}$

Indeed, 'charitable trusts' are an important part of the offshore world. Interest earned by a charitable trust offshore cannot be taxed, and the loan back to the high-net-worth individual (HNWI) is also tax-free because it is now transformed into a 'debt'. Here, we see how profits earned through exchange or other methods can, via gifts and debt payments, end up circumventing tax payments, and can discursively invoke a rhetoric of charitable obligation to obviate obligations to the state or society at large.

What is the scale of offshore finance? Far from a marginal or exotic backwater of the global economy, offshore in many ways is the global economy. While estimates are extremely difficult to make given the problems of measurement, scale, and secrecy for any financial sector activity, the TJN (a non-profit advocacy network discussed further below) estimates that US $\$ 11.5$ trillion is held offshore by HNWIs alone. This figure does not account for corporate assets (TJN 2005). This is a conservative estimate, based on a triangulation of data from the Bank for International Settlements, Merrill Lynch/Cap Gemini, Boston Consulting Group, and McKinsey and Company. Other estimates are that between one-fifth and one-half of all the world's money is at any given point in time located in an offshore jurisdiction. The IMF estimated in 2000 that $50 \%$ of cross-boundary bank assets were intermediated through offshore centers, down from 56\% in 1991.

While the absolute magnitude of offshore finance is difficult to measure, something of its ordinal position in the world economy can be gleaned from the Bank for International Settlement banking statistics (which, because they only measure cash deposits, miss all other kinds of assets like stocks, bonds, and real estate or other assets held by offshore trusts or companies). In rank order, then, at the end of 2006, the Cayman Islands were the world's sixth largest banking center in terms of assets. Jurisdictions like the Isle of Man occupy a comparable position to Norway; the Bahamas, to Austria (see Table 1). The group of countries in the top 12 has remained relatively stable since the late 1990s, with some movement due to the changing status of Hong Kong.

Furthermore, a worldwide growth in the number of HNWIs has propelled a lucrative global business in tax and estate planning (Rawlings 2005, 2007). In 1991, the Society for Trust and Estate Practitioners (STEP) was formed to represent the interests of the professionals serving this field. STEP 
Table 1. Top 12 banking centers, ranked by assets, December 2006 (in US\$ billions).

\begin{tabular}{llr}
\hline 1. & UK & 5178.5 \\
2. & Germany & 2794.0 \\
3. & United States & 2305.1 \\
4. & France & 2196.1 \\
5. & Japan & 1898.5 \\
6. & Cayman Islands & 1661.9 \\
7. & Switzerland & 1122.0 \\
8. & The Netherlands & 1041.5 \\
9. & Belgium & 891.6 \\
10. & Ireland & 819.1 \\
11. & Hong Kong SAR & 621.4 \\
12. & Singapore & 603.5 \\
\hline
\end{tabular}

Source: Bank for International Settlements.

became an important player in the late 1990s and early 2000s in challenging the multilateral regulatory effort aimed at offshore finance. Eden and Kudrle (2005) argue that further research must be conducted on actors like international tax and accounting firms, as well as organizations like STEP that promote and benefit from the regulatory arbitrage possibilities created by differential tax regimes.

In the section that follows, I turn to the reasons for renewed attention to offshore finance in the mid-1990s, the regulatory responses, and the effects of those initiatives.

\section{The Idea of 'Harmful Tax Competition'}

Picciotto (2007) traces the emergence of political and social movement concern over offshore finance to the series of financial scandals and crises that developed in the wake of the reliberalization of finance in the 1980s. From the Mexican Peso Crisis of 1994-1995 to the Asian Financial Crisis of 1997-1998 and the spectacular failures of Barings Bank, Sumitomo, and Long-Term Capital Management, footloose global finance has been in the public spotlight, a fact that perhaps also accounts for the rise in the social sciences of a new field devoted to the social study of financial markets. The potential for offshore centers to be used for criminal money laundering and tax evasion had always made tax havens sources of concern for the regulatory agencies of states. Yet, the conflict for states seeking to please business interests yet to protect their own revenue base had come to a head with the neoliberal paradigm of Reagan/Thatcher. While the G7 and other international organizations had earlier worked to create an anti-money laundering (AML) regime, epitomized in the creation of the FATF in 1989, less effort at the international level had been directed toward controlling 
tax evasion or tax avoidance. This was due in no small measure to the so-called Revenue Rule, the 18th-century legal principle of state sovereignty articulated by Lord Mansfield that 'no country ever takes notice of the revenue laws of another' (Holman v. Johnson, 98 Eng. Rep. II20, II2I [K.B. I775]). The revenue rule is at the heart of the modern fiscal state (Cameron 2006). While competitive deregulation and 'tax competition' among states to draw foreign investment is a challenge to the revenue rule and the fiscal state, in the ideology of neoliberalism this challenge serves as a useful check on government excess. Indeed, parties that lined up against international efforts to crack down against tax havens explicitly touted tax competition as a guarantee of freedom from state infringements of (economic) liberty.

Still, fears of global financial instability in the wake of the peso and Asian financial crises spurred industrialized states to develop multilateral mechanisms for monitoring and improving the global financial architecture. Two new multilateral initiatives grew directly from G7 concerns, and a third was initiated by the FATF. The OECD Committee on Fiscal Affairs, established in 1996, was charged with the task of understanding and addressing what came to be known as 'tax competition' in destabilizing or distorting international financial flows. Tax competition referred to the competitive lowering of tax rates by countries seeking to attract foreign investment. It is assumed to challenge the sovereign power of states to fund their traditional functions. In the ensuing international debate over tax havens, tax competition came to signify the challenges to states posed by economic globalization. As Webb (2004) points out, however, tax competition is the expected or imagined outcome of a specific, liberal economic theory, and not necessarily a measurable reality in the world. Governments 'certainly behave as if tax competition has increased' (Webb 2004, 788), and that behavior helps propel government and intergovernmental policymaking. Hobson (2003) argues that rather than a race to the bottom, there has been a race to the middle (see also Vlcek 2007).

The FSF, established in 1999, was a direct consequence of G7 concerns about global financial stability (see Picciotto 2007, 2-5). The FSF promulgated its Compendium of Standards (www.fsforum.org/compendium/ about.html), a set of internationally accepted financial, economic, and accounting standards for the maintenance of sound financial systems, and it reports to the IMF and the World Bank on countries' varying degrees of acceptance or implementation of those standards. In May 2000, the FSF released a ranking of offshore centers 'least likely . . to promote the stability of the global financial system' (Sharman 2006, 35), but this effort received much less attention, and was decidedly less confrontational, than the OECD and FATF approach that followed.

On the heels of its first report, Harmful Tax Competition: An Emerging Global Issue (1998), the OECD launched the most controversial aspect of its effort to address tax haven abuses: the publishing of annual 'blacklists' 
of jurisdictions not in compliance with the OECD recommendations and standards. The OECD released its first blacklist of jurisdictions to be 'named and shamed' in June 2000. In advance of that release, six jurisdictions made 'advance commitments' to bring their country's laws into compliance with the OECD's recommendations and so managed to stay off the blacklists. Ironically, this included two of the most significant offshore financial centers, the Cayman Islands and Bermuda (the other four were Cyprus, Malta, Mauritius, and San Marino).

In addition, in June 2000, the FATF issued its first blacklist of 'NonCooperative Countries and Territories' (NCCT). Unlike the OECD, which focused on 'harmful tax competition', the FATF emphasized compliance with its Forty Recommendations against money laundering and criminal financial activity. In the aftermath of the terrorist attacks on September 11, 2001, the FATF added nine 'Special Recommendations' on terrorist financing, heralding the creation of a new 'anti-money laundering, and combating the financing of terrorism' (AML-CFT) regime, subsequently adopted by the World Bank (www1.worldbank.org/finance/html/amlcft/ referenceguide.htm). The events of September 11, 2001, also shifted the focus to information sharing, and the Bush administration's coolness to the idea of curtailing tax competition permitted a pro-market, pro-surveillance regime in line with that administration's broader agendas.

What drew immediate attention in 2000, however, was the blacklists themselves. J. C. Sharman, who has written a comprehensive analysis of the effort to achieve global tax regulation, notes that the publication of OECD and FATF blacklists went against these organizations' traditional consensusbased and 'lead-by-example' approach (Sharman 2006, 33). Their confrontational measures met with an equally confrontational response from leaders of the blacklisted jurisdictions charged with being 'non-cooperative'. Caribbean leaders, for example, charged the OECD and FATF with bullying and charged that the whole affair was a neocolonial effort to subjugate present and former dependencies right at the moment when they had achieved success in the global economy (Sanders 2002, 326; Sanders 2005). Other jurisdictions, having complied with earlier FATF recommendations, felt that they were unfairly being hounded by multilateral organizations that were nothing more than rich nations' clubs. For example, the member states of the Caribbean Financial Action Force, which formed as the result of meetings in 1990 and 1992, had already been cooperating with the FATF on the implementation of the Forty Recommendations, and then suddenly found themselves the targets of the OECD's tax competition initiative.

Meanwhile, various non-governmental organizations identified tax evasion and tax justice as a key issue for developing economies in the late 1990s, as well, lending moral force to the OECD's and FATF's program. Most notable among these was Oxfam, which tied offshore finance and tax evasion directly to the plight of the poor in developing countries. Wealthy elites' use of offshore centers for 'asset protection' was linked by Oxfam and others to 
the erosion of the revenue base in countries like those of sub-Saharan Africa that could ill afford it. For Oxfam, the term 'harm' inaugurated in the phrase 'harmful tax competition' took on a literal, visceral meaning. Oxfam's report was even more significant given that it estimated the revenue loss to developing countries to be US $\$ 50$ billion per year - roughly, the same amount as the annual cost of the United Nations' Millennium Development Goals (TJN 2007). The TJN, founded in 2002 at the European Social Forum, has kept the linkage between tax revenue loss and poverty in the forefront, at least for academics and activists involved in the offshore.

What caused a country to be blacklisted? There were four main criteria: low or no tax on income from financial services; the 'ring-fencing' of financial activities from the rest of the domestic economy; a lack of transparency; and a lack of information sharing provisions. The OECD was careful to distinguish a 'preferential' tax regime from a 'harmful preferential' tax regime. This was because it was hesitant to claim that low tax rates, in and of themselves, were 'harmful'. To do so would be to undercut the liberal economic ideology of some of the OECD's member states (see Webb 2004).

Table 2 and Figure 1 present the changing composition of the OECD and FATF blacklists over time. Many were quick to point out the hypocrisy of the blacklists. Switzerland and Luxembourg, both OECD members and prominent financial centers themselves, strenuously opposed the effort from the beginning, mainly behind the scenes but also in the form of memos appended to OECD reports indicating their abstention. But it was the OECD's own governing principles of consensus, deliberation, and peer review that ultimately undid its efforts at global tax regulation.

\section{From Tax Competition to the Level Playing Field}

Heretofore, the OECD, FATF, and other multilateral bodies had attempted to create new regulatory regimes through the creation and dissemination of standards and best practices, and through a procedure of peer monitoring and review. The issuing of blacklists represented a new strategy. Given their historical emphasis on peer consultation and peer review, and charges of neocolonialism and hypocrisy, the FATF and especially the OECD were compelled to invite offshore centers themselves to the table.

The possible damage to offshore jurisdictions' reputations by being blacklisted led them quickly to seek to minimize the damage. Most sought to get themselves off the blacklists by adopting best practices proposed by the OECD and FATF or by issuing press releases committing themselves to compliance. Sharman, Rawlings, and others have all amply documented this process (Maurer 2005; Rawlings 2005; Sharman 2006; Webb 2004; Woodward 2006). All the while, a discursive war raged over the OECD's concepts and definitions.

The main parties opposed to the OECD were the STEP, as noted earlier a professional association of fiduciary firms including estate and succession 


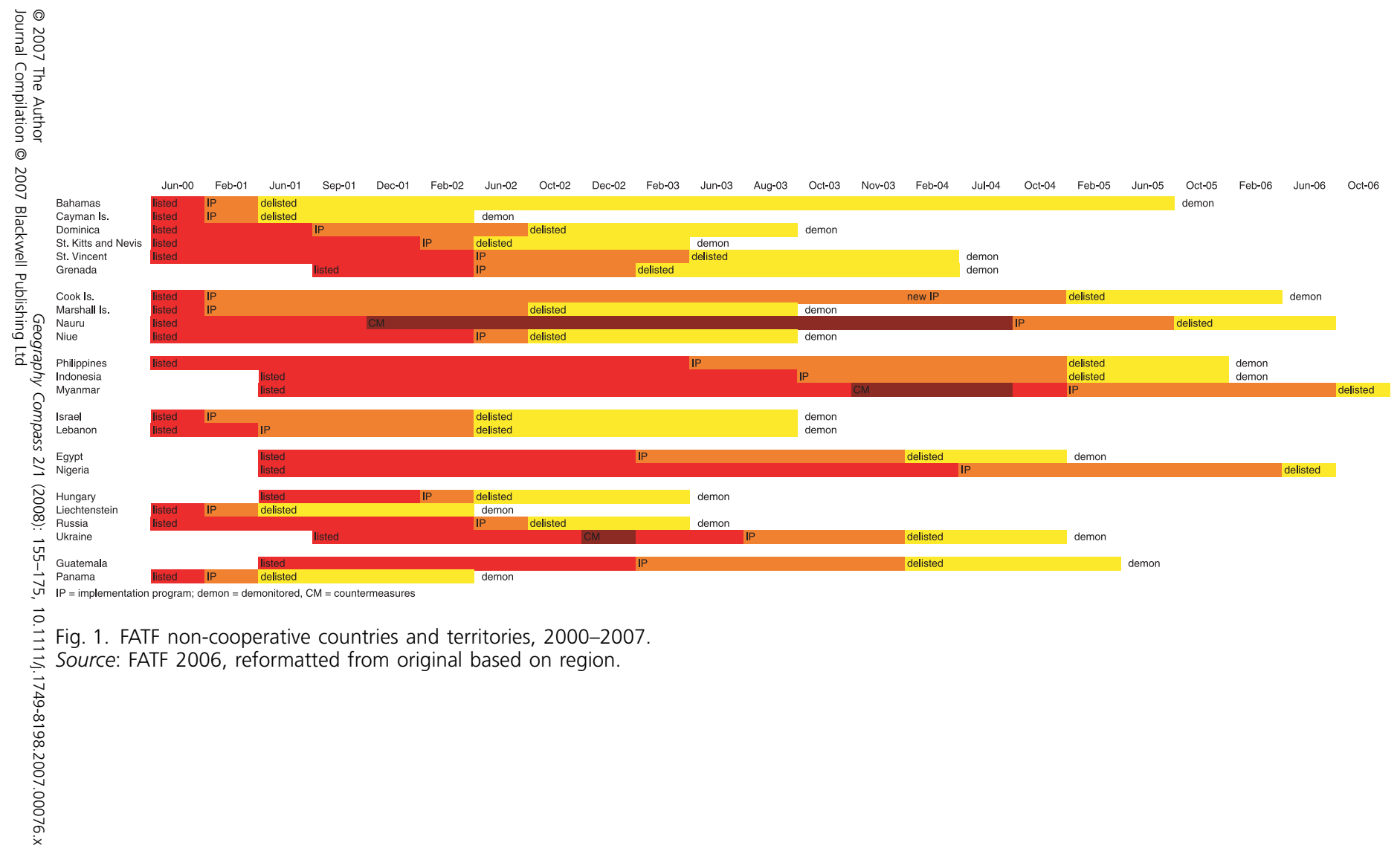


Table 2. OECD harmful tax competition lists, 2000-2007.

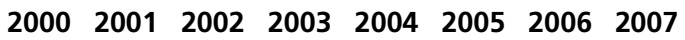

\begin{tabular}{|c|c|c|c|c|c|c|c|c|c|}
\hline Caribbean Region & & & & & & & & & \\
\hline Anguilla & & $x$ & $x$ & & & & & & \\
\hline Antigua and Barbuda & & $x$ & $x$ & & & & & & \\
\hline Aruba & & $x$ & & & & & & & \\
\hline Bahamas & & $x$ & $x$ & & & & & & \\
\hline Barbados & & $x$ & $x$ & & & & & & \\
\hline Bermuda & $A C$ & & & & & & & & \\
\hline British Virgin Islands & & $x$ & $x$ & & & & & & \\
\hline The Cayman Islands & $A C$ & & & & & & & & \\
\hline Dominica & & $\mathrm{X}$ & $\mathrm{X}$ & & & & & & \\
\hline Grenada & & $\mathrm{X}$ & $\mathrm{X}$ & & & & & & \\
\hline Montserrat & & $\mathrm{X}$ & $\mathrm{X}$ & & & & & & \\
\hline Netherlands Antilles & & $\mathrm{X}$ & & & & & & & \\
\hline St. Kitts and Nevis & & $\mathrm{X}$ & $x$ & & & & & & \\
\hline St. Lucia & & $\mathrm{X}$ & $\mathrm{X}$ & & & & & & \\
\hline St. Vincent and Grenadines & & $\mathrm{X}$ & $\mathrm{X}$ & & & & & & \\
\hline Turks and Caicos & & $\mathrm{X}$ & $\mathrm{X}$ & & & & & & \\
\hline US Virgin Islands & & $x$ & $x$ & & & & & & \\
\hline Central America & & & & & & & & & \\
\hline Belize & & $x$ & $x$ & & & & & & \\
\hline Guatemala & & & & & & & & & \\
\hline Panama & & $x$ & $x$ & & & & & & \\
\hline Pacific Ocean & & & & & & & & & \\
\hline Cook Islands & & $x$ & $x$ & & & & & & \\
\hline Marshall Islands & & $x$ & $x$ & $x$ & $x$ & $x$ & $x$ & $x$ & $x$ \\
\hline Nauru & & $x$ & $x$ & $x$ & & & & & \\
\hline Nive & & $x$ & $x$ & & & & & & \\
\hline Tonga & & $x$ & & & & & & & \\
\hline Vanuatu & & $x$ & $x$ & $x$ & & & & & \\
\hline Western Samoa & & $x$ & $x$ & & & & & & \\
\hline Africa and the Middle East & & & & & & & & & \\
\hline Bahrain & & $x$ & & & & & & & \\
\hline Liberia & & $x$ & $x$ & $x$ & $x$ & $x$ & $x$ & $x$ & $x$ \\
\hline Europe & & & & & & & & & \\
\hline Andorra & & $x$ & $x$ & $x$ & $x$ & $x$ & $x$ & $x$ & $x$ \\
\hline Cyprus & $A C$ & & & & & & & & \\
\hline Gibraltar & & $x$ & $x$ & & & & & & \\
\hline Guernsey/Sark/Alderney & & $x$ & $x$ & & & & & & \\
\hline Isle of Man & & $x$ & & & & & & & \\
\hline Jersey & & $x$ & $x$ & & & & & & \\
\hline Malta & $A C$ & & & & & & & & \\
\hline Lichtenstein & & $x$ & $x$ & $x$ & $x$ & $x$ & $x$ & $x$ & $x$ \\
\hline Monaco & & $x$ & $x$ & $x$ & $x$ & $x$ & $x$ & $x$ & $x$ \\
\hline San Marino & $A C$ & & & & & & & & \\
\hline Indian Ocean & & & & & & & & & \\
\hline Mauritius & $A C$ & & & & & & & & \\
\hline Maldives & & $x$ & $x$ & & & & & & \\
\hline Seychelles & & $x$ & & & & & & & \\
\hline
\end{tabular}

AC, advance commitment. 
planners and tax advisors; the Center for Freedom and Prosperity, a Washington, DC think tank; and the International Tax and Investment Organization (later renamed the International Trade and Investment Organization, ITIO), a multilateral body of tax haven countries that was established with the assistance of the Commonwealth Secretariat, explicitly modeled on the OECD as a consultative body made up of representatives from its own member states and entities with observer status. ${ }^{3}$

The logic of the OECD demanded that the ITIO be incorporated into its own process of consultation as a participating partner. The result was the creation of the Global Forum on Taxation, which would meet every 2 years under the auspices of the OECD. The Global Forum consisted of OECD and non-OECD members, including the ITIO membership. The discourse of harmful tax competition very quickly shifted to 'principles of transparency and effective exchange of information for tax purposes' (OECD 2003). Furthermore, the emphasis shifted to:

$[\mathrm{H}]$ ow to achieve a global level playing field and how to improve further the process by which this initiative can be taken forward based on the widely accepted principles of equity and shared responsibility. (ibid.)

Shortly after this OECD statement, the ITIO issued its own press release, headlined 'It's Official: OECD Tax Project Depends on Level Playing Field' (ITIO 2003). The chief outcome of the first Global Forum meeting was the creation of a 'Level Playing Field Joint Working Group'. The 'level playing field' slogan has by now made its was into the title of nearly every major report by the OECD and other parties to the tax competition debate, including the title of the OECD's own report on the 2005 Global Forum meeting (OECD 2006), and a 2007 report by the Commonwealth Secretariat titled Assessing the Playing Field (Stoll-Davey 2007).

The effect of the inclusion of the ITIO into the Global Forum has been a kind of politics by press release (after Rawlings's phrase, 'compliance by press release'; Rawlings 2007, 59). At the close of the 2007 Global Forum meeting and the release of the Commonwealth Secretariat report, the ITIO issued a press release headed:

\section{LITTLE DIFFERENCE BETWEEN ONSHORE AND OFFSHORE, NEW ANALYSIS OF OECD DATA REVEALS \\ 'End stigmatization and let us into treaty network', say small countries Commonwealth calls for fair play}

The release concludes:

Big countries operate through clubs and use organizations that they control (OECD, FATF, IMF, FSF, etc.) to establish and promulgate rules, standards of practice and intended norms. They call these 'international standards' and impose them on weaker states. Small and developing states feel unfairly pressured to apply standards not uniformly applied by those countries which are applying the pressure or by other more powerful competitor countries. 
In his introduction to the ITIO report, Ransford Smith, Deputy Secretary-General of the Commonwealth Secretariat, states: 'In the global arena the lack of representation and effective participation of small vulnerable economies in international standard setting bodies and processes is one of the major drawbacks. The small states have limited opportunities to make inputs into the development of measures that are critical for the efficient functioning of the sector, as well as for their development. Yet their compliance is expected within given timeframes'. (ITIO 2007, 6; original formatting)

The press release echoes the discourse of much of the tax competition debate, framing the issue in terms of weak versus strong states and calling into question the universality of rules and practices devised by the few and the powerful. This is a profoundly postcolonial rhetoric, drawing on legacies of imperial rule and touting the principles of liberty, equality, and fairness. It also draws on the supposed equality of states in the international system: note that the ITIO frames its demand in terms of access to the regime of international treaty-making rather than multilateral consensus-making bodies. The ITIO, in effect, has harnessed the postcolonial network of expertise embodied in the Commonwealth Secretariat (which, earlier, had issued two volumes in support of small states' 'fiscal sovereignty': Antoniou 2004 and Biswas 2002) to challenge the OECD initiative not just in the name of sovereignty, but also in the name of global anticolonial struggle.

In addition, the deployment of the level playing field had another 'liberal' effect. Originally, the OECD and FATF measures had marked a convergence in OECD and FATF interests, bringing together two issues once held apart: tax evasion and money laundering (Sharman 2006, 34). However, the rhetoric of the level playing field, together with concessions on information sharing, pushed the two issues apart again. Compliance with the OECD and FATF became a technical matter of tax preferences rather than corporate tax rates or collection. In 2006, the last country on the FATF NCCT list, Myanmar, was removed, and the IMF formally ended FATF blacklisting.

\section{Effects of the Effort at Global Tax Regulation}

It would be a mistake, however, to argue that the OECD and FATF initiatives were entirely without effect. Tax haven jurisdictions did seek to comply, and compliance had a number of tangible and practical consequences. For example, new financial services commissions, separate from government finance ministries, were established; corporate registries were formed; Know Your Customer and due diligence procedures were put in place. All of this increased the costs of running an offshore center, leading some of the more marginal ones, particularly in the Pacific, effectively to cease operations. But according to Vlcek (2007), there has been little change in overall offshore assets. Compliance may have placed 'speed bumps' (Sunder Rajan 2003) on the byways of offshore capital mobility, but Hampton 
and Christensen's (2002) prediction of the demise of offshore finance has not come true.

This is not to say that the OECD, FATF, and related efforts did not have any effect on the island economies that often host offshore finance centers. Vlcek (2007) documents a decline in employment opportunities in several Caribbean jurisdictions, as well as declining state revenues. He also notes a shift of some activity to Singapore, a non-OECD member. Still, for the case of the Bahamas, for example, despite a decline in assets on deposit from 2000 to 2003 , deposits in 2003 are higher than any time during the period from 1994-1999 (Vlcek 2007, 341-342). And while there has been a decline in the number of banks, suggesting new barriers to entry, there has been an increase in mutual funds and hedge funds in the offshore Caribbean.

In the British Virgin Islands, business incorporations matter much more than banking per se, given the territory's historical emphasis on its signature international business company vehicle. After the establishment of the British Virgin Islands Financial Services Commission, a key component of the British Virgin Islands compliance regime, incorporation dipped slightly. Nevertheless, there has been a $44 \%$ increase in the international business companies on the books from 2002 to 2005 (British Virgin Islands Financial Services Commission 2006a,b). As for employment, while the number of Registered Agents and service providers has declined, there has been an increase in the number of jobs available in the offshore sector, particularly in the Financial Services Commission itself. Ethnographic research in the British Virgin Islands may complicate the picture further, for these jobs seem to be going to members of the islands' historical elites, families from Road Town, Anegada, and the Valley on Virgin Gorda. This reverses a pattern of civil service jobs going to people from other, historically poorer parts of the islands (see Maurer 1997).

The effort did result in an information sharing regime, but one based on 'on demand' requests rather than the automatic provision of information. Anonymous corporate ownership has been curtailed offshore by the immobilization of bearer shares and the creation of corporate registries. However, as numerous commentators have pointed out, many onshore jurisdictions continue to permit anonymous corporate ownership. Writing for STEP, Hay (2006) notes that a major unintended consequence of the disappearance of anonymous corporate ownership offshore has been its proliferation in US states like Delaware, which permits anonymous beneficial ownership, and Nevada and Wyoming, which permit bearer shares (Hay 2006; OECD 2006). The IMF even concluded, in 2004, 'compliance levels for offshore financial centers are, on average, more favorable than those for other jurisdictions assessed by the Fund' (IMF 2004, 7). The US Government Accountability Office reported much the same, in its 2006 survey of corporate ownership information ('most states do not require ownership information at the time a company is formed'; Government Accountability Office 2006). Senator Carl Levin put it more pointedly at an earlier stage of the harmful 
tax competition debate, and in reference to the offshore tax practices deemed 'harmful' by the OECD: 'we are basically doing the same thing' (The Economist 2002, 99). The European Union Savings Tax Directive, which seeks to implement an information exchange and withholding tax regime on European Union natural persons and was brought into effect in 2005 nonetheless exempts several key European Union member states until 2010; not surprisingly, these include Switzerland and Luxembourg, the two holdouts from the OECD harmful tax competition initiative, as well as Belgium and Austria, known for bank secrecy.

Hay (2006) and Sharman (2006) both point out that one effect of the effort at global tax regulation has been the monitoring of onshore regimes and concern over the reputation for impartiality of organizations like the OECD. The OECD was definitely affected by allegations of its hypocrisy, and, as Sharman argues, the performative aspects of the debate over harmful tax competition demonstrate the importance of speech acts and reputation over brute force in many aspects of international relations (Sharman 2006). The effort also significantly revived offshore sovereignty: Rawlings (2007) discusses the remarkable increase in Tax Information Exchange Agreements (TIEA) made between offshore and onshore jurisdictions, which enhance small states' sovereignty by making them equal parties to bilateral international treaties. It also puts paid to multilateralism.

\section{The Missing Piece: Payment, and Efforts to Avoid it}

Palan (2003) remarks that the 'nomad millionaires' who make use of the offshore demonstrate that sovereignty no longer refers to territorial control, but rather to gatekeeping. For Palan, it is a mistake for analysts to differentiate the 'real' economy from the 'fictions' of the offshore world. While we know that Panama or Liberia are not 'really' the centers of international shipping, to use one of Palan's examples, our knee-jerk assessment of their fictionality is based on our commitment to an isomorphism of power and place (Palan 2003, 177-78). But the world looks different from a 'non-territorial' perspective, where trajectories and gateways matter more than points and where accounting devices may subsume that which they supposedly merely record (Palan 2003, 170).

In the social study of finance, fascination with finance's fictions has tended to take attention away from the way the very distinction between fact and fiction itself empowers certain understandings of the economy as beyond human control and as solidly and uniformly capitalist in character. GibsonGraham (2006) and Callon (1998), in different ways, analyze the role of such distinctions in not only discursively stabilizing 'the economy' as a monolithic entity but in constituting it, while rendering undiscussable all the elements of what we could call alternative economies lurking within or trundling alongside it. There is a corresponding tendency, however, to see these alternatives as utopian or libratory. As I suggested at the start of this essay, 
greater analytical attention to the distinction between exchange and payment might offer conceptual and political avenues for rethinking the offshore. This is not to suggest that payments, based on obligation and rank rather than liberty and equality, are necessarily a happier alternative to market exchange. Bribery, extortion and taxes - which Bourdieu (1998, 43) relates to one another as species of the same - have a sordid past and an equally insalubrious present.

But payments are difficult to think about precisely because of the downplaying of relationships of rank in a world supposedly governed by principles of contract and free exchange. Offshore finance is not always and not everywhere such a world. HNWI wealth is often inherited wealth, for one thing. As the hypothetical example from Braithwaite (2001) quoted above demonstrates, HNWI wealth is also channeled through 'charity' into 'debt' and back again in order to evade payments to states. In addition, tax havens have historically taken root in jurisdictional anomalies - holdovers of empires, feudal city-states, territories never fully incorporated into the Westphalian system of nation-states. And relationships of rank clearly govern multilateral and international organizations, which are still the preserve of certain historically wealthy or historically militarily victorious countries seeking to preserve their status.

Sharman (2005) explicitly calls for a strategy of reducing tax haven abuses by buying them off. Oxfam (2000) called for some form of compensation for tax havens in return for their efforts to reduce harmful tax competition. Some jurisdictions might be extremely expensive to buy off, such as the Cayman Islands or Bermuda. Others, such as Liechtenstein and Monaco, might be nearly impossible due to royal interference. Still others, like Dubai, have managed through TIEAs and Double Taxation Treaties (DTTs) to avoid being labeled a tax haven and have themselves been attempting to buy out large holdings in OECD member states. But some jurisdictions might very well take up the offer: Sharman (2005) documents Nauru's request for US $\$ 10$ million in return for AML compliance (p. 320). On the one hand, such a strategy could be seen as a fair trade, or an exchange: for a relatively small investment, OECD countries could recoup substantial lost tax revenue. The countries listed on the OECD's 2000 blacklist reported a combined government revenue of less than US $\$ 13$ billion dollars. The Internal Revenue Service estimates that Caribbean tax havens alone cost the US $\$ 70$ billion per year in lost income tax revenue (Sharman 2006, 152-153). It would seem a rather simple calculation, and in the best interests of all involved - to pay US $\$ 13$ billion and save US $\$ 70$ billion, a US $\$ 57$ billion profit.

On the other hand, buying the havens off also complicates the idea of a market in sovereignty or a race to the bottom. Sometimes, things are not all on the same scale, or even on the same kind of scale (see Guyer 2004). Offshore finance has become the lifeblood of many small island economies, particularly in the Caribbean, where legacies of slavery and colonialism are not imagined to remain in the distant past but rather always in evidence 
in the conduct of international affairs and everyday encounters in tourist or financial settings. Here, compensation comes to appear more like reparations. This is why Sharman's emphasis on reputation is so important: reputation is about hierarchies of rank, not about equivalence or a market of equals.

Coming to grips with offshore finance and harmful tax competition may mean coming to re-appreciate, analytically and politically, the politics of those hierarchies of rank. Solutions adequate to them may very well be part of the language-games we associate with payments rather than exchanges, and here we may come up against the limits of our analytical vocabulary and political imagination. An obligation to pay can be imagined in a manner similar to a tithe or to philanthropy, or along the lines of a 'Tobin tax' on cross-boundary financial transactions to fund global human welfare. At the very least, however, we can imagine a world where the obligation to pay taxes is incumbent on those of high rank - for even feudal lords graced their subjects with redistributed tribute.

\section{Acknowledgements}

I would like to thank Tom Boellstorff and Gregory Rawlings for their helpful comments on earlier drafts. All errors remain my responsibility alone. Research on Caribbean offshore financial services and the OECD initiative has been supported by the National Science Foundation (SES-0516861). Any opinions, findings, and conclusions or recommendations expressed in this article are those of the author and do not necessarily reflect the views of the National Science Foundation.

\section{Short Biography}

Bill Maurer is Professor and Chair of the Department of Anthropology at the University of California, Irvine, CA, USA. He has written widely on the anthropology of money, finance and property for Cultural Anthropology, American Ethnologist, American Anthropologist, Annual Reviews in Anthropology, Environment and Planning D: Society and Space, Comparative Studies in Society and History, and other venues. He is the editor of several collections, as well as the author of Recharting the Caribbean: Land, Law and Citizenship in the British Virgin Islands (1997), Pious Property: Islamic Mortgages in the United States (2006), and Mutual Life, Limited: Islamic Banking, Alternative Currencies, Lateral Reason (2005). The latter received the Victor Turner Prize in 2005.

\section{Notes}

* Correspondence address: Bill Maurer, Department of Anthropology, University of California, Irvine, 3151 Social Sciences Plaza, Irvine, CA 92697-5100, USA. E-mail: wmmaurer@uci.edu.

1 Another solution is for tax havens to enter into Tax Information Exchange Agreements or Double Taxation Treaties on a bilateral basis with onshore countries. This both empowers offshore states' sovereignty in the international system of states, as Rawlings (2007) explains and 
as discussed later in this essay, and it allows offshore centers to play more powerful countries off against each other. For example, Rawlings (personal communication, August 28, 2007) reports that Vanuatu has been successful in pitting the United States against Australia by agreeing to assist the former in it its effort against 'terrorist financing' and thereby ignore Australian pleas for assistance in countering 'tax evasion'.

${ }^{2}$ Rawlings indicates that in reality the set up might be much more complicated than this. I would like to thank him for his assistance in helping me think about such examples where exchange and payment 'intersect in ambiguous and unexpected ways' (Rawlings, personal communication, August 28, 2007).

${ }^{3}$ The members of the ITIO are: Anguilla, Antigua and Barbuda, Bahamas, Barbados, Belize, British Virgin Islands, Cayman Islands, St. Kitts and Nevis, St. Lucia, St. Vincent and the Grenadines, Turks and Caicos Islands, Panama, Cook Islands, Samoa, Vanuatu. The observers are the Commonwealth Secretariat, CARICOM Secretariat, Caribbean Development Bank, Eastern Caribbean Central Bank, Pacific Islands Forum Secretariat.

\section{References}

Antoniou, A. (ed.) (2004). International financial services sectors in small vulnerable economies: challenges and prospects. London: Commonwealth Secretariat.

Biswas, R. (ed.) (2002). International tax competition: globalisation and fiscal sovereignty. London: Commonwealth Secretariat.

Bourdieu, P. (1998). Rethinking the state: genesis and structure of the bureaucratic field. In: Bourdieu, P. (ed.) Practical reason. Cambridge, UK: Polity, pp. 35-63.

Braithwaite, J. (2001). Through the eyes of the advisers: a fresh look at tax compliance of high wealth individuals. Working Paper No. 21, Center for Tax System Integrity, Australian National University, Canberra, Australia. [online]. Retrieved on 28 August 2007 from http://ctsi.anu. edu.au/publications/WP/21.pdf

British Virgin Islands Financial Services Commission. (2006a). FSC Statistical Bulletin 1, March 2006. [online]. Retrieved on 25 August 2007 from http://www.bvifsc.vg/DesktopModules/ Bring2mind/DMX/Download.aspx?EntryId=136\&PortalId=2\&DownloadMethod=attachment

—. (2006b). FSC Statistical Bulletin 5, December 2006. [online]. Retrieved on 25 August 2007 from http://www.bvifsc.vg/DesktopModules/Bring2mind/DMX/Download.aspx?EntryId $=354 \&$ Portalld $=2 \&$ DownloadMethod $=$ attachment

Callon, M. (1998). The embeddedness of economics markets in economics. In: Callon, M. (ed.) The laws of the markets. Oxford, UK: Blackwell, pp. 1-57.

Cameron, A. (2006). Turning point? The volatile geographies of taxation. Antipode 38, pp. 236-258.

De Goede, M. (2005). Resocialising and repoliticising financial markets: contours of social studies of finance. Economic Sociology European Electronic Newsletter 6 (3), pp. 19-28. [online]. Retrieved on 25 August 2007 from http://econsoc.mpifg.de/archive/esjuly05.pdf

Donaghy, M. (2002). Formality and informality in offshore financial centres. Social Identities 8 (2), pp. 271-286.

Donaghy, M., and Clarke, M. (2003). Are offshore financial centres the product of global markets? A sociological response. Economy \& Society 32 (3), pp. 381-409.

Eden, L., and Kudrle, R. T. (2005). Tax havens: renegade states in the international tax regime? Law \& Policy 27 (1), pp. 100-127.

Financial Action Task Force. (2006). Annual review of non-cooperative countries and territories. [online]. Retrieved on 25 August 2007 from http://www.fatf-gafi.org/dataoecd/0/0/37029619.pdf

Gibson-Graham, J. K. (2006). The end of capitalism (as we knew it): a feminist critique of political economy. Minneapolis, MN: University of Minnesota Press.

Government Accountability Office. (2006). Corporate formation: minimal ownership information is collected and available. Report to the Permanent Subcommittee on Investigations, Committee on Homeland Security and Governmental Affairs, U.S. Senate. [online]. Retrieved on 25 August 2007 from http://www.gao.gov/new.items/d06376.pdf

Guyer, J. (2004). Marginal gains: monetary transactions in Atlantic Africa. Chicago, IL: University of Chicago Press. 
Hampton, M. P. (1994). Treasure islands or fool's gold? Can and should small island economies copy Jersey? World Development 22 (2), pp. 237-250.

Hampton, M. P., and Abbott, J. P. (1999). The rise (and fall?) of offshore finance in the global economy: editors' introduction. In: Hampton, M. P. and Abbott, J. P. (eds) Offshore finance centres and tax havens. London: Macmillan Press, pp. 1-17.

Hampton, M. P., and Christensen, J. (2002). Offshore pariahs? Small island economies, tax havens, and the re-configuration of global finance. World Development 30 (9), pp. 1657-1673.

Hay, R. J. (2006). OECD level playing field report released: consensus or conflict? Tax Planning International Review June 2006, pp. 1-8.

Hobson, J. M. (2003). Disappearing taxes or the 'race to the middle'? Fiscal policy in the OECD. In: Weiss, L. (ed.) States in the global economy: bringing domestic institutions back in. Cambridge, UK: Cambridge University Press.

Hudson, A. C. (1998). Placing trust, trusting place: on the social construction of offshore financial centres. Political Geography 17 (8), pp. 915-937

- (2000). Offshoreness, globalization and political sovereignty: a postmodern geo-political economy? Transactions of the Institute of British Geographers 25, pp. 269-283.

IMF (2000). Offshore financial centers: IMF background paper. [online]. Retrieved on 25 August 2007 from http://www.imf.org/external/np/mae/oshore/2000/eng/back.htm

— . (2004). Offshore financial centers: the assessment program. An update $12 \mathrm{March}$ 2004. [online]. Retrieved on 25 August 2007 from http://www.imf.org/external/np/mfd/2004/eng/ 031204.htm

ITIO (2003). It's official: OECD tax project depends on level playing field. Press release, International Trade and Investment Organization. [online]. Retrieved on 25 August 2007 from http:// www.itio.org/NewPressReleases/PR23-10-03.htm

- (2007). Little difference between onshore and offshore, new analysis of OECD data reveals. Press release, International Trade and Investment Organization. [online]. Retrieved on 25 August 2007 from http://www.itio.org/pdf/ITIO_press_release_1_May2007.pdf

Maurer, B. (1997). Recharting the Caribbean: land, law and citizenship in the British Virgin Islands. Ann Arbor, MI: University of Michigan Press.

- (2004). Finance. In: Carrier, J. (ed.) Handbook of economic anthropology. Cheltenham, UK: Edward Elgar Publishers Ltd., pp. 176-193.

—_. (2005). Due diligence and 'reasonable man', offshore. Cultural Anthropology 20 (4), pp. $474-505$.

- (2008). From the Revenue Rule to Soft Law and Back Again: The Consequences for 'Society' of the Social Governance of International Tax Competition. In: Eckert, J., von Benda Beckmann, K. and von Benda Beckmann, F. (eds). Rules of law and laws of ruling. London: Ashgate, forthcoming.

OECD (1998). Harmful tax competition - an emerging global issue. Organization for Economic Cooperation and Development. [online]. Retrieved on 25 August 2007 from http:// www.oecd.org/dataoecd/33/1/1904184.pdf

- (2003). OECD Global Forum on Taxation, Ottawa, 14-15 October. Closing Statement by the Co-Chairs. [online]. Retrieved on 25 August 2007 from http://www.oecd.org/document /0/0,3343,en_2649_201185_16643264_1_1_1_1,00.html

- (2006). Tax cooperation: towards a level playing field. 2006 Assessment by the Global Forum on Taxation. Paris: OECD.

Oxfam (2000). Tax havens: releasing the hidden billions for poverty eradication. Oxfam Policy Report. [online]. Retrieved on 25 August 2007 from http://publications.oxfam.org.uk/oxfam/display. asp?K=20040623_2316_000034

Palan, R. (2003). The offshore world: sovereign markets, virtual places, and nomad millionaires. Ithaca, NY: Cornell University Press.

Picciotto, S. (1999). Offshore: the state as legal fiction. In: Hampton, M. P. and Abbott, J. P. (eds) Offshore finance centres and tax havens. London: Macmillan Press, pp. 43-79.

- (2007). Tackling tax havens and 'offshore' finance. Paper presented at the seminar on Money Laundering, Tax Evasion and Financial Regulation, Transnational Institute, Amsterdam, 12-13 June 2007. [online]. Retrieved on 25 August 2007 from http://www.tni.org/crime-docs/ picciotto.pdf 
Rawlings, G. (2004). Laws, liquidity, and Eurobonds: the making of the Vanuatu tax haven. Journal of Pacific History 39 (3), pp. 325-341.

- (2005). Mobile people, mobile capital and tax neutrality: sustaining a market for offshore finance centres. Accounting Forum 29 (3), pp. 289-310.

- (2007). Taxes and transnational treaties: responsive regulation and the reassertion of offshore sovereignty. Law \& Policy 29 (1), pp. 51-66

Roberts, S. M. (1994). Fictitious capital, fictitious spaces: the geography of offshore financial flows. In: Corbridge, S. Martin, R. and Thrift, N. (eds) Money, power, and space. Oxford, UK: Blackwell, pp. 91-115.

Sanders, R. M. (2002). The fight against fiscal colonialism: the OECD and small jurisdictions. The Round Table: Commonwealth Journal of International Affairs 365, pp. 325-348.

- (2005). Crumbled small: the Commonwealth Caribbean in world politics. London: Hansib Publications.

Sharman, J. C. (2005). South Pacific tax havens: from leaders in the race to the bottom to laggards in the race to the top? Accounting forum 29 (3), pp. 311-323.

. (2006). Havens in a storm: the struggle for global tax regulation. Ithaca, NY: Cornell University Press.

Stoll-Davey, C. (2007). Assessing the playing field: international cooperation in tax information exchange. London: Commonwealth Secretariat.

Sunder Rajan, K. (2003). Genomic capital: public cultures and market logics of corporate biotechnology. Science as culture 12 (1), pp. 87-121.

The Economist (2002). Shell games. 26 October, p. 99.

TJN (2005). Briefing paper - the cost of offshore. Tax Justice Network Report. [online]. Retrieved on 25 August 2007 from http://www.taxjustice.net/cms/upload/pdf/Price_of_Offshore.pdf

- (2007). Closing the floodgates: collecting tax to pay for development. Tax Justice Network Report. [online]. Retrieved on 25 August 2007 from http://www.globalpolicy.org/nations/ launder/haven/2007/2007taxjustice.pdf

Vlcek, W. (2007). Why worry? The impact of the OECD harmful tax competition initiative on Caribbean offshore financial centres. The Round Table: Commonwealth Journal of International Affairs 96, pp. 331-346.

Webb, M. C. (2004). Defining the boundaries of legitimate state practice: norms, transnational actors and the OECD's project on harmful tax competition. Review of International Political Economy 11 (4), pp. 787-827.

Woodward, R. (2006). Offshore strategies in global political economy: small islands and the case of the EU and OECD harmful tax competition initiatives. Cambridge Review of International Affairs 19 (4), pp. 685-699. 